\title{
Ecthyma gangrenosum: a report of eight cases*
}

\author{
César Adrián Martínez-Longoria ${ }^{1}$ \\ Jorge Ocampo-Garza ${ }^{3}$ \\ Jorge Ocampo-Candiani ${ }^{3}$
}

\author{
Gloria María Rosales-Solis ${ }^{2}$ \\ Guillermo Antonio Guerrero-González ${ }^{3}$
}

DOI: http:/ / dx.doi.org/10.1590/abd1806-4841.20175580

\begin{abstract}
Ecthyma gangrenosum is a rare skin infection classically associated with Pseudomonas aeruginosa. We performed a retrospective study of all cases diagnosed with ecthyma gangrenosum from 2004-2010 in a university hospital in Mexico (8 cases, 5 female patients and 3 male patients, ages between 4 months and 2 years). The most common risk factor for ecthyma gangrenosum is neutropenia in immunocompromised patients. In previously healthy patients, immunological evaluation is important to rule out underlying immunodeficiency. Ecthyma gangrenosum in healthy patients has a high mortality rate and early diagnosis and aggressive antibiotic treatment is imperative as it can improve patients' prognosis.
\end{abstract}

Keywords: Ecthyma; Pseudomonas; Pseudomonas aeruginosa; Pseudomonas infections

\section{INTRODUCTION}

Ecthyma gangrenosum (EG) is a rare skin infection classically associated with Pseudomona aeruginosa. It can be a potentially fatal systemic infection and can be a manifestation of an underlying clinical entity. ${ }^{1-3}$

We performed a retrospective study of all EG cases from 2004 to 2010 in a university hospital in Monterrey, Mexico.

\section{CASE REPORT}

We report 8 cases that occurred with 5 female patients and 3 male patients, ages between 4 months and 2 years. Four patients were apparently previously healthy at admission, and the other 4 had a degree of immunosuppression (hemophagocytic lymphohistiocytosis, undifferentiated embryonic liver sarcoma and desnutrition (Table 1)). All patients presented at our institution in a febrile state. They also had a history of erythema that progressed to pustules and ulcerations surrounded by erythema, some of them covered by a necrotic crust. Two patients had the lesions on the face, 3 on the extremities, 1 in the supraclavicular region, 1 in the gluteal region, and 1 on the face and extremities (Figures 1 and 2). Workup was significant for neutrophilia in 3 patients, neutropenia in 4 patients, thrombocytopenia in 7 patients, and thrombocytosis in 1 patient. Bacteria blood cultures from 7 patients grew Pseudomona aeruginosa. The patient with negative blood culture showed a positive result in the bacterial wound culture for Pseudomona aeruginosa. On immunological investigation, 2 of the apparently healthy children were diagnosed with granulomatous chronic disease, with dihydrorhodamine 123 (DHR). Seven patients received combination therapy (4 ceftazidime and amikacin, 2 imipenem and amikacin, 1 meropenem and amikacin, and 1 meropenem and ciprofloxacin) and 1 received monotherapy with imipenem. Five patients had favorable evolution, with resolution of the skin lesions and with close follow-up. Three patients (including the 2 previously healthy) died secondary to sepsis.

\section{DISCUSSION}

The most common risk factor for EG is neutropenia in immunocompromised patients. Although it rarely occurs in previously healthy patients, $50 \%$ of these patients reveal a primary subclinical immunodeficiency or underwent recent antibiotic therapy., In previously healthy patients, the immunological evaluation is important to rule out underlying immunodeficiencies. ${ }^{2}$

EG has also been described in association with other pathogens including Aeromonas hydrophila, Staphylococcus aureus, Streptococcus pyogenes, Serratia marcescens, Klebsiella pneumoniae, Xan-

Received on 14.01.2016.

Approved by the Advisory Board and accepted for publication on 09.01.2017.

* Work performed at the Department of Dermatology. University Hospital “Dr. José Eleuterio González". Universidad Autónoma de Nuevo León - Monterrey, Mexico

Financial support: none.

Conflict of interest: none.

Tecnológico de Monterrey Clinic - Monterrey, México

Department of Pediatrics, University Hospital “Dr. José Eleuterio González”, Universidad Autónoma de Nuevo León - Monterrey, México

Department of Dermatology, University Hospital “Dr. José Eleuterio González”, Universidad Autónoma de Nuevo León - Monterrey, México

(C)2017 by Anais Brasileiros de Dermatologia 
thomonas maltophilia, Morganella morganii, Escherichia coli, Citrobacter freundii, Corynebacterium diphtheriae, Neisseria gonorrhoeae, Yersinia pestis, Candida albicans, Aspergillus fumigatus, Mucormycosis, Fusarium solani, Scytalidium dimidiatum, Pseudallescheria boydii, and Curvularia species. ${ }^{1-3}$

Two types of EG have been described: the classical or bacteremic form, secondary to hematogenous spread; and the localized EG or nonsepticemic form, in which the lesion is located at the site of inoculation of the organism into the skin. ${ }^{1}$

Antibiotic therapy with spectrum for Pseudomonas aeruginosa includes aminoglycosides, third- and fourth-generation ceph- alosporins, $\beta$-lactam antibiotics, and broad-spectrum penicillins. In addition to the results of susceptibility tests for the isolate from the patient, local patterns of susceptibility for each hospital should be considered in the initial choice of treatment. Some studies comparing combination therapy with monotherapy reveal that the regimens do not affect mortality rates. ${ }^{5-7}$

Prognosis depends on the host and on the degree of immunosuppression. ${ }^{4}$ The disease has a high mortality rate. In patients with EG and septicemia secondary to Pseudomonas, it ranges from $38 \%-77 \%$, and in patients with no sepsis, it is described in about $15 \% .{ }^{8}$ The most important prognostic factor of mortality in invasive

TABLE 1: Study of 8 cases with ecthyma gangrenosum

\begin{tabular}{|c|c|c|c|c|c|c|c|}
\hline Case & Age/Sex & Localization & $\begin{array}{l}\text { Previously healthy or } \\
\text { immunocompromised }\end{array}$ & Laboratory findings & Hemoculture & Treatment & Outcome \\
\hline 1 & 9 months & Face & $\begin{array}{l}\text { Previously healthy } \\
\text { Granulomatous chronic } \\
\text { disease }\end{array}$ & $\begin{array}{l}\text { Neutrophilia } \\
\text { Thrombocytopenia }\end{array}$ & + & $\begin{array}{l}\text { Ceftazidime and } \\
\text { amikacin }\end{array}$ & Favorable \\
\hline 2 & $\begin{array}{l}10 \text { months } \\
\text { Male }\end{array}$ & Extremities & $\begin{array}{l}\text { Previously healthy } \\
\text { Granulomatous chronic } \\
\text { disease }\end{array}$ & $\begin{array}{l}\text { Neutrophilia } \\
\text { Thrombocytosis }\end{array}$ & + & $\begin{array}{l}\text { Ceftazidime and } \\
\text { amikacin }\end{array}$ & Favorable \\
\hline 3 & $\begin{array}{l}13 \text { months } \\
\text { Female }\end{array}$ & Face & $\begin{array}{l}\text { Immunocompromised } \\
\text { Desnutrition }\end{array}$ & $\begin{array}{l}\text { Leukopenia } \\
\text { Thrombocytopenia }\end{array}$ & + & Imipenem & Favorable \\
\hline 4 & $\begin{array}{l}5 \text { months } \\
\text { Female }\end{array}$ & Gluteal region & $\begin{array}{l}\text { Immunocompromised } \\
\text { Hemophagocytic } \\
\text { lymphohistiocytosis }\end{array}$ & $\begin{array}{l}\text { Neutropenia } \\
\text { Thrombocytopenia }\end{array}$ & + & $\begin{array}{l}\text { Ceftazidime and } \\
\text { amikacin }\end{array}$ & Favorable \\
\hline 5 & $\begin{array}{l}5 \text { months } \\
\text { Female }\end{array}$ & $\begin{array}{l}\text { Face and } \\
\text { extremities }\end{array}$ & $\begin{array}{l}\text { Immunocompromised } \\
\text { Desnutrition }\end{array}$ & $\begin{array}{l}\text { Neutrophilia } \\
\text { Thrombocytopenia }\end{array}$ & + & $\begin{array}{l}\text { Ceftazidime and } \\
\text { amikacin }\end{array}$ & Deceased \\
\hline 6 & $\begin{array}{l}4 \text { months } \\
\text { Female }\end{array}$ & Extremities & Previously healthy & $\begin{array}{l}\text { Neutropenia } \\
\text { Thrombocytopenia }\end{array}$ & - & $\begin{array}{l}\text { Imipenem and } \\
\text { amikacin }\end{array}$ & Deceased \\
\hline 7 & $\begin{array}{l}2 \text { years } \\
\text { Female }\end{array}$ & $\begin{array}{l}\text { Supraclavicular } \\
\text { region }\end{array}$ & $\begin{array}{l}\text { Immunocompromised } \\
\text { Undifferentiated } \\
\text { Embryonic Liver Sarcoma }\end{array}$ & $\begin{array}{l}\text { Neutropenia } \\
\text { Thrombocytopenia }\end{array}$ & + & $\begin{array}{l}\text { Meropenem and } \\
\text { ciprofloxacin }\end{array}$ & Favorable \\
\hline 8 & $\begin{array}{l}6 \text { months } \\
\text { Male }\end{array}$ & Extremities & Previously healthy & Thrombocytopenia & + & $\begin{array}{l}\text { Meropenem and } \\
\text { amikacin }\end{array}$ & Deceased \\
\hline
\end{tabular}

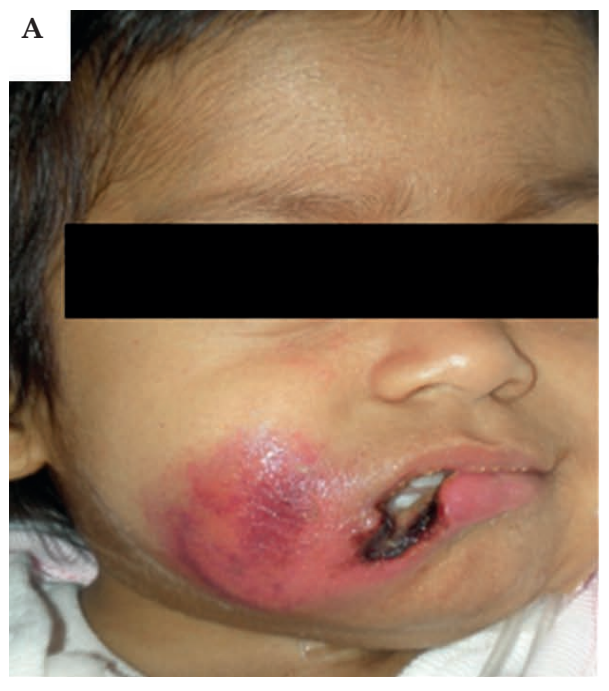

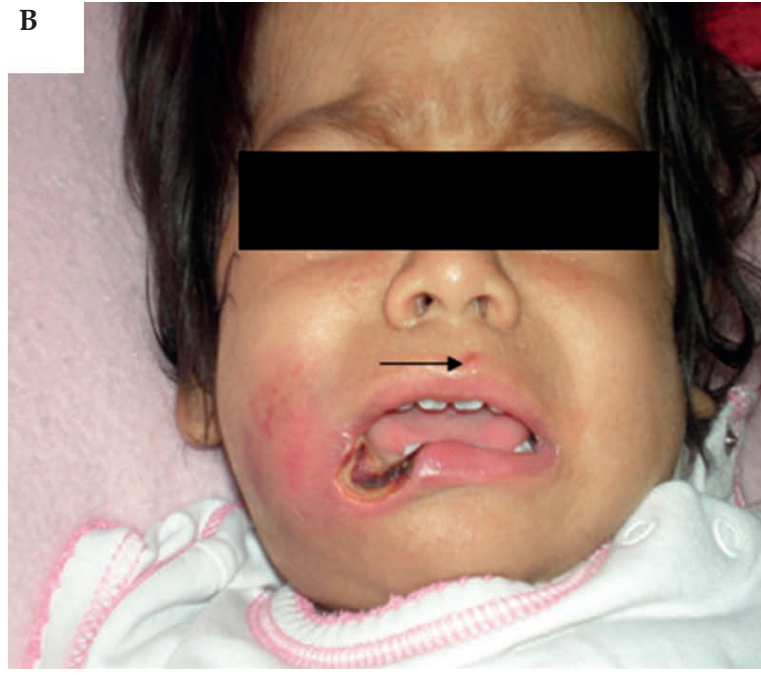

Figure 1:

Ecthyma gangrenosum. (A) Day 4 of hospitalization: patient presenting with erythema and edema on the left cheek. Lower lip showing ulceration with necrotic tissue; (B) day 7 showing new erythematous areas on the upper lip 

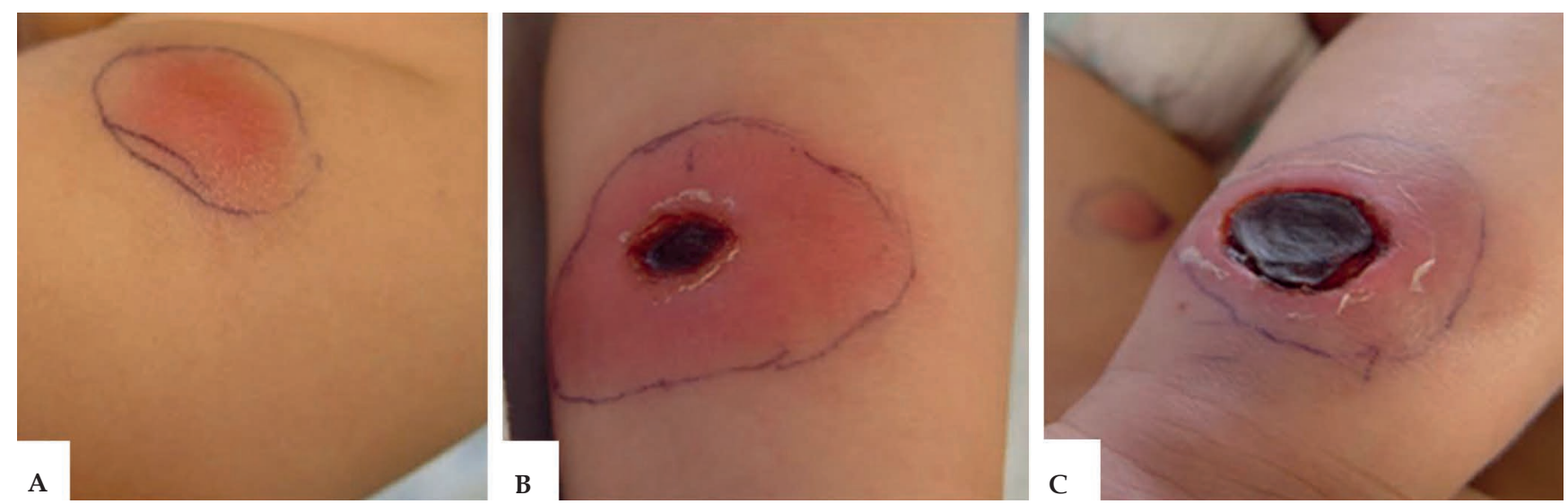

FiguRE 2: Progression of ecthyma gangrenosum on the left arm. (A) Initial presentation with erythematous nodule; (B) increase in size of the area with erythema and ulceration; (C) Ulceration with central necrotic crust

forms is the presence of neutropenia at diagnosis. ${ }^{9}$ Luigi et al. reported that severe sepsis by $P$. aeuruginosa can occur in previously healthy children with a mortality rate of $55 \% .^{10}$

Immunological evaluation is essential in all the patients (including the apparently healthy ones) as immunosuppression can drastically change the prognosis. EG in healthy patients has a high mortality rate and early diagnosis and aggressive antibiotic treatment is imperative as it can improve the patient's prognosis. $\square$

\section{REFERENCES}

1. Reich HL, Williams Fadeyi D, Naik NS, Honig PJ, Yan AC. Nonpseudomonal ecthyma gangrenosum. J Am Acad Dermatol. 2004;50:S114-7.

2. Zomorrodi A, Wald ER. Ecthyma gangrenosum: considerations in a previously healthy child. Pediatr Infect Dis J. 2002;21:1161-4.

3. Tsuchiyama K, Okuyama R, Ogawa E, Inoue A, Ishizawa $\mathrm{K}$, Harigae $\mathrm{H}$, et al. Ecthyma gangrenosum with Citrobacter freundii infection. J Eur Acad Dermatol Venereol. 2009;23:709-10.

4. Baro M, Marín MA, Ruiz-Contreras J, de Miguel SF, Sánchez-Díaz I. Pseudomonas aeruginosa sepsis and ecthyma gangrenosum as initial manifestations of primary immunodeficiency. Eur J Pediatr. 2004;163:173-4.

5. Gargouri L, Maaloul I, Kamoun T, Maalej B, Safi F, Majdoub I, et al. Ecthyma gangrenosum: A manifestation of community-acquired Pseudomonas aeruginosa septicemia in three infants. Arch Pediatr. 2015;22:616-20

6. $\quad$ Khan F, Saul T. Ecthyma gangrenosum. J Emerg Med. 2012;43:e133-4.

7. Hu Y, Li L, Li W, Xu H, He P, Yan X, et al. Combination antibiotic therapy versus monotherapy for Pseudomonas aeruginosa bacteraemia: a meta-analysis of retrospective and prospective studies. Int J Antimicrob Agents. 2013;42:492-6.

8. Chan YH, Chong CY, Puthucheary J, Loh TF. Ecthyma gangrenosum: a manifestation of Pseudomonas sepsis in three pediatric patients. Singapore Med J. 2006:47:1080-3.

9. Prego J, Bello 0, Dufort y Alvarez G, de Leonardis D, Sehabiague G, Imbriaco $\mathrm{H}$, Pizzorno E. Shock séptico por Pseudomonas aeruginosa adquirido en la comunidad asociado a neutropenia, en un paciente previamente sano. Arch Pediatr Urg. 2006;77:144-8.

10. Viola L, Langer A, Pulitanò S, Chiaretti A, Piastra M, Polidori G. Serious Pseudomonas aeruginosa infection in healthy children: case report and review of the literature. Pediatr Int. 2006;48:330-3.

\author{
MAILING ADDRESS: \\ Guillermo Antonio Guerrero-González \\ Av. Francisco I. Madero Pte. S/N y Av. Gonzalitos, \\ Col. Mitras Centro, \\ 64460 Monterrey, Nuevo León, Mexico. \\ E-mail:guillermoguerrerog@gmail.com
}

How to cite this article: Martínez-Longoria CA, Rosales-Solis GM, Ocampo-Garza J, Guerrero-Gonzalez GA, Ocampo-Candiani J. Ecthyma gangrenosum: a report of eight cases. An Bras Dermatol. 2017;92(5):698-700. 